\title{
Konsep Penanganan Sanitasi Permukiman Kumuh di Kecamatan Lowokwaru, Kota Malang
}

\author{
Sanitation Treatment Concept From Slum Settlement at Lowokwaru \\ Subdistrict in Malang City
}

\author{
Hasan $^{1}$, Ibnu Sasongko $^{1}$, Titik Poerwati ${ }^{1}$ \\ Diterima: 6 Agustus 2018 Disetujui: 19 November 2019
}

\begin{abstract}
Abstrak: Sanitasi merupakan salah satu kriteria permasalahan permukiman kumuh di Kota Malang yang meliputi masalah persampahan, air limbah, dan drainase. Masalah tersebut tersebar di 5 Kecamatan di Kota Malang salah satunya adalah Kecamatan Lowokwaru. Berbagai penanganan telah dilakukan baik dari pemerintah maupun masyarakat untuk mengatasi masalah sanitasi di Kecamatan Lowokwaru diantaranya adalah penanganan sanitasi di RW 3 \& RW 6 Kelurahan Dinoyo, RW 5 dan RW 7 Kelurahan Tlogomas, dan RW 9 Kelurahan Jatimulyo. Oleh karena itu, penelitian ini bertujuan untuk mengetahui konsep penanganan sanitasi di lokasi tersebut. Metode pengumpulan data yang digunakan dalam penelitian ini adalah observasi, wawancara, dan kuesioner. Metode analisa data yang digunakan adalah metode statistik deskriptif, metode skoring, dan metode klaster. Kesimpulan dalam penelitian ini adalah terdapat 3 jenis konsep penanganan sanitasi yang telah diterapkan di lokasi penelitian yaitu percontohan, partisipatori, dan bantuan.
\end{abstract}

\section{Kata kunci : konsep penanganan, permukiman kumuh, sanitasi}

\begin{abstract}
Sanitation is one of the criteria of slum settlement problems in Malang City, covering the problem of solid waste, waste water, and drainage. The problem is spread in 5 subdistricts in Malang City, one of which is Lowokwaru Sub-district. Various treatment has been done both from the government and society to solve sanitation problems in Lowokwaru Subdistrict, including sanitation handling in RW 3 \& RW 6 Dinoyo, RW 5 and RW 7 Tlogomas, and RW 9 Jatimulyo. Therefore, this study aims to find out the concept of sanitation handling in these locations. Data collection methods used in this study are observation, interviews, and questionnaires. Data analysis methods used are descriptive statistical methods, scoring methods, and cluster methods. The conclusion in this study is there are 3 types of concepts that are applied in the research locations are pilot, partisipatory, and assistance.
\end{abstract}

Keywords : treatment concept, sanitation, slum settlement

\section{PENDAHULUAN}

Kawasan kumuh pada umumnya merupakan kawasan dengan sanitasi yang buruk dan yang menjadi salah satu masalah perkotaan yang terjadi di kota-kota besar di Indonesia. Buruknya kondisi sanitasi seringkali dipicu oleh ketidakmampuan penduduk

\footnotetext{
${ }^{1}$ Program Studi Perencanaan Wilayah \& Kota, Institut Teknologi Nasional Malang
} 
secara ekonomi untuk menyediakan sanitasi yang layak dalam hal penyediaan air bersih, penyaluran limbah, pengelolaan persampahan, dan kondisi drainase lingkungan yang memadai (Isti,2014).

Kota Malang merupakan salah satu kota yang terletak di Provinsi Jawa Timur. Kota ini merupakan salah satu kota penyumbang kekumuhan di Indonesia. Hal ini tidak mengherankan karena Kota Malang merupakan salah satu Kota di Indonesia yang memiliki pertumbuhan dan perkembangan kota yang sangat cepat baik dalam pertumbuhan fisik maupun ekonomi (Danny,2016). Hal ini dibuktikan dengan penetapan Peraturan Daerah (Perda) Nomor 12 Tahun 2014 tentang Rencana Pembangunan dan Pengembangan Perumahan dan Kawasan Permukiman (RP3KP) Kota Malang. Dalam keputusan Walikota Malang Nomor 188.45/86/35.73.112/2015 Tentang Penetapan Lingkungan Perumahan dan Permukiman Kumuh, luasan kawasan kumuh di Kota Malang adalah seluas 608,60 Ha yang meliputi 29 kelurahan pada 5 kecamatan di Kota Malang.

Tabel 1. Permasalahan Sanitasi Permukiman Kumuh di Kota Malang

\begin{tabular}{|c|c|c|c|}
\hline No & Kriteria & Masalah & $\begin{array}{l}\text { Prosentase } \\
(\%)\end{array}$ \\
\hline \multirow{3}{*}{1} & \multirow{3}{*}{ Air limbah } & $\begin{array}{l}\text { Bangunan hunian pada lokasi permukiman tidak memiliki kloset (leher } \\
\text { angsa) yang terhubung dengan septic tank. }\end{array}$ & \multirow[t]{2}{*}{15} \\
\hline & & $\begin{array}{l}\text { Saluran pembuangan air limbah rumah tangga tercampur dengan } \\
\text { drainase lingkungan. }\end{array}$ & \\
\hline & & & 22 \\
\hline 2 & $\begin{array}{l}\text { Pengelolaan } \\
\text { sampah }\end{array}$ & $\begin{array}{l}\text { Sampah domestik rumah tangga pada kawasan permukiman terangkut ke } \\
\text { TPS/TPA kurang dari } 2 \text { minggu sekali. }\end{array}$ & 14 \\
\hline \multirow[t]{2}{*}{3} & Drainase & \multirow[t]{2}{*}{$\begin{array}{l}\text { Kondisi jaringan drainase pada lokasi permukiman memiliki kualitas } \\
\text { buruk. }\end{array}$} & 14 \\
\hline & Jumlah & & 95 \\
\hline
\end{tabular}

Sumber: SK Kumuh Kota Malang, 2015

Dari tabel di atas, dapat dilihat bahwa masalah sanitasi merupakan salah satu masalah yang mendominasi permukiman kumuh di Kota Malang dengan total $95 \%$. Melihat tingginya prosentase permasalahan sanitasi , berbagai penanganan telah dilakukan baik dari pemerintah maupun masyarakat untuk mengatasi masalah sanitasi di Kecamatan Lowokwaru, oleh karena itu penelitian ini bertujuan untuk mengetahui konsep penanganan sanitasi di lokasi tersebut. Penelitian ini terdiri atas 3 sasaran, yakni mengidentifikasi ketersediaan prasarana sanitasi di lokasi penelitian, mengidentifikasi tingkat permasalahan sanitasi di lokasi peneltian, dan merumuskan konsep penanganan sanitasi di lokasi penelitian. Sanitasi dalam penelitian ini diuraikan berdasarkan elemen sanitasi yaitu sampah, limbah, dan drainase.

Lokasi dalam penelitian ini adalah Kecamatan Lowokwaru dengan mengambil 3 kelurahan, yakni Kelurahan Dinoyo, Tlogomas, dan Jatimulyo. Untuk Kelurahan Dinoyo tepatnya di RW 3 dan RW 6, Kelurahan Tlogomas terdapat di RW 5 dan RW 7, sedangkan Kelurahan Jatimulyo terdapat di RW 9. Kecamatan Lowokwaru merupakan salah satu kecamatan di Kota Malang yang memiliki luas wilayah sebesar 22,6 $\mathrm{km}^{2}$ yang terdiri atas 12 kelurahan. Kelurahan Dinoyo, Tlogomas, dan Jatimulyo merupakan kelurahankelurahan yang terdapat di Kecamatan Lowokwaru dengan luas masing-masing $1,17 \mathrm{~km}^{2}$, $1,86 \mathrm{~km}^{2}$, dan 2,51 $\mathrm{km}^{2}$. Kelurahan Dinoyo terdiri atas $7 \mathrm{RW}$ (Rukun Warga) dan $51 \mathrm{RT}$ (Rukun Tetangga), Kelurahan Tlgomas terdiri atas 9 RW (Rukun Warga) dan 49 RT (Rukun Tetangga), dan Kelurahan Jatimulyo terdiri atas 10 RW (Rukun Warga) dan 51 RT (Rukun Tetangga). 


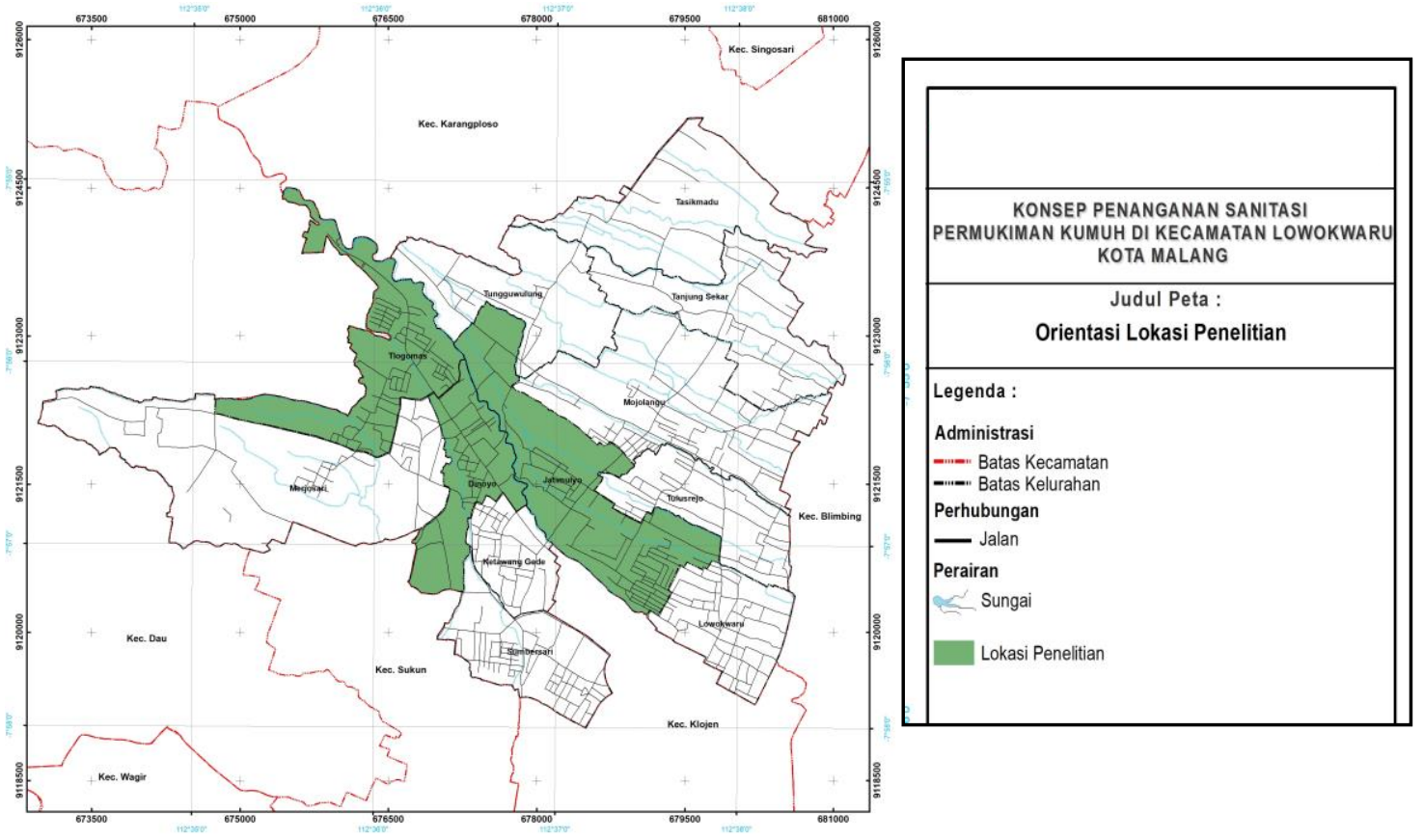

Sumber : Rencana Tata Ruang Wilayah (RTRW) Kota Malang Tahun 2010-2030

\section{Gambar 2. Orientasi Lokasi Penelitian}

Menurut Brikke dan Bredero (2003) dalam (Isti,2014), sanitasi merupakan suatu usaha pengendalian terhadap seluruh faktor-faktor fisik, kimia, dan biologi dalam lingkungan hidup manusia, yang menimbulkan suatu kerusakan atau terganggunya perkembangan dan kesehatan baik fisik, mental maupun sosial serta kelangsungan kehidupan manusia. Dalam pengertian lain, Menurut Owoyeye (2013) sanitasi lingkungan dinyatakan sebagai kontrol dari semua faktor dalam lingkungan fisik manusia yang dapat merusak pada perkembangan fisik, kesehatan dan kelangsungan hidup. masalah sanitasi lingkungan disebabkan oleh kondisi drainase, penyaluran limbah dan persampahan yang buruk. Menurut UN Water (2008) dalam Jovanni (2016) elemen sanitasi terdiri atas sanitasi dasar rumah tangga, manajemen limbah padat rumah tangga, drainase alir limbah rumah tangga dan air hujan serta pengelolaan limbah industri.

Sampah adalah benda yang dihasilkan dari berbagai benda yang telah digunakan dan tidak diperlukan lagi oleh manusia (Mohammad, 2011). Dalam pengertian lain, sampah adalah sisa kegiatan sehari-hari manusia dan/atau dari proses alam yang berbentuk padat (Suyoto, 2008) dalam Riswan (2011). Agar tercipta sistem persampahan yang bagus diperlukan prasarana persampahan dan sistem pengelolaan yang memadai. Prasarana persampahan meliputi tempat sampah, gerobak sampah, TPS (Tempat Pembuangan Sementara) dan TPA (Tempat Pembuangan Akhir). Sistem pengelolaan persampahan meliputi pemilahan, pewadahan, pegumpulan, pemindahan, dan pengangkutan (Permen PU no. 2,2016).

Air limbah adalah cairan buangan dari rumah tangga, industri maupun tempattempat umum lain yang mengandung bahan-bahan yang dapat membahayakan kehidupan manusia maupun makhluk hidup lain serta mengganggu kelestarian lingkungan (Metcaff \& Eddy, 1993) dalam (Lorensius,dkk,2014). Selanjutnya limbah domestik adalah air bekas 
yang tidak dapat dipergunakan lagi untuk tujuan semula baik yang mengandung kotoran manusia (tinja) atau dari aktivitas dapur, kamar mandi, dan cuci. Limbah domestik digolongkan ke dalam 2 jenis, yaitu grey water dan black water. Grey water merupakan air bekas cucian dapur, mesin cuci, dan kamar mandi, sedangkan Black water, merupakan tinja (faeces) yang berpotensi mengandung mikroba pathogen dan air seni, umumnya mengandung Nitrogen $(\mathrm{N})$ dan Fosfor, serta mikroorganisme.

Menurut Joy (2011), terdapat 2 macam sistem pengelolaan limbah domestik/ permukiman yaitu sistem pengelolaan air limbah setempat (on-site system) dan terpusat (off site system). Sistem pengelolaan air limbah setempat (on-site system), yaitu sistem dimana fasilitas pengelolaan air limbah berada dalam persil atau batas tanah yang dimiliki, fasilitas sanitasi individual seperti septic tank. Sistem pengelolaan air limbah terpusat (offsite system) atau sistem sewerage, yaitu sistem dimana fasilitas pengelolaan air limbah berada di luar persil atau dipisahkan dengan batas jarak atau tanah yang menggunakan perpipaan untuk mengalirkan air limbah dari rumah-rumah secara bersamaan dan kemudian dialirkan ke IPAL.

Drainase berasal dari bahasa Inggris yaitu drainage yang mempunyai arti mengalirkan, menguras, membuang atau mengalihkan air. Drainase juga dapat diartikan sebagai suatu tindakan teknis untuk mengurangi kelebihan air yang berasal dari air hujan, rembesan, maupun kelebihan air irigasi dari suatu kawasan atau lahan, sehingga fungsi kawasan atau lahan tidak terganggu (Nurhapni,2013).

\section{METODE}

Metode dalam penelitian ini terdiri atas metode pengumpulan data dan metode analisa data. Metode pengumpulan data menggunakan cara observasi, wawancara, dan kuesioner. Untuk wawancara terdiri atas 5 narasumber yang masing-masing merupakan ketua RW (Rukun Warga) di lokasi penelitian, sedangkan untuk kuesioner menggunakan sampel sebanyak 370 KK (Kepala Keluarga). Pengambilan sampel ini menggunakan metode random sampling dengan menggunakan rumus Taro Yamane. Presisi sampel yang ditetapkan adalah $10 \%$. Berikut ini merupakan tabel rincian jumlah sampel di lokasi penelitian.

Tabel 2. Jumlah Sampel di Lokasi Penelitian

\begin{tabular}{rlll}
\hline No & Lokasi & Populasi & Sampel \\
\hline 1 & RW 3 Kelurahan Dinoyo & 256 & 71 \\
2 & RW 6 Kelurahan Dinoyo & 218 & 68 \\
3 & RW 5 Kelurahan Tlogomas & 240 & 67 \\
4 & RW 7 Kelurahan Tlogomas & 529 & 84 \\
5 & RW 9 Kelurahan Jatimulyo & 423 & 80 \\
& Jumlah & & 370 \\
\hline
\end{tabular}

Sumber: Kajian Peneliti , 2018

Metode analisa data menggunakan metode analisa statistik deskriptif, metode analisa skoring, dan metode analisa klaster. Berikut ini disajikan rumusan variabel yang digunakan dalam penelitian ini :

Tabel 3. Rumusan Variabel Penelitian

\begin{tabular}{clll}
\hline No & Variabel & Sub Variabel & Definisi Operasional \\
\hline \multirow{2}{*}{ Fisik } & Ketersediaan prasarana sanitasi & $\begin{array}{l}\text { Ketersediaan masing-masing prasarana sanitasi } \\
\text { yang terdiri atas prasarana persampahan, } \\
\text { prasarana limbah, dan prasarana drainase. }\end{array}$
\end{tabular}




\begin{tabular}{|c|c|c|c|}
\hline No & Variabel & Sub Variabel & Definisi Operasional \\
\hline \multirow{5}{*}{2} & & Dimensi prasarana sanitasi & $\begin{array}{l}\text { Ukuran masing-masing prasarana sanitasi yang } \\
\text { terdiri atas ukuran prasarana persampahan, } \\
\text { ukuran prasarana limbah, dan ukuran prasarana } \\
\text { drainase. } \\
\text { Kondisi masing-masing prasarana sanitasi vang }\end{array}$ \\
\hline & & Kondisi prasarana Sanitasi & $\begin{array}{l}\text { Kondisi masing-masing prasarana sanitasi yang } \\
\text { terdiri atas kondisi prasarana persampahan, } \\
\text { kondisi prasarana limbah, dan kondisi prasarana } \\
\text { drainase. }\end{array}$ \\
\hline & \multirow{3}{*}{ Pelaksanaan } & Sistem pengelolaan sanitasi & $\begin{array}{l}\text { Sistem pengelolaan dari prasarana sanitasi yang } \\
\text { terdiri atas sistem pengelolaan persampaha dan } \\
\text { sistem pembuangan limbah. }\end{array}$ \\
\hline & & Peran pemerintah & $\begin{array}{l}\text { Peran pemerintah dalam mengatasi masalah } \\
\text { sanitasi. }\end{array}$ \\
\hline & & Peran masyarakat & $\begin{array}{l}\text { Peran masyarakat dalam mengatasi masalah } \\
\text { sanitasi. }\end{array}$ \\
\hline 3 & Perilaku & Kebiasaan masyarakat & $\begin{array}{l}\text { Kebiasaan masyarakat dalam membuang } \\
\text { sampah dan air limbah. }\end{array}$ \\
\hline
\end{tabular}

Sumber: Kajian Peneliti , 2018

\section{HASIL DAN PEMBAHASAN} penelitian.

Hasil dan pembahasan memuat hasil analisa yang diuraikan berdasarkan sasaran

1. Ketersediaan Prasarana Sanitasi

Variabel yang digunakan adalah variabel fisik dari masing-masing elemen sanitasi yakni sampah, limbah, dan drainase. Adapun hasil analisa ketersediaan prasarana sanitasi adalah sebagai berikut :

a. Prasarana Persampahan

Prasarana persampahan meliputi tempat sampah, gerobak sampah, dan TPS sementara.

1) Tempat sampah : Jumlah tempat sampah terbanyak adalah RW 6 Kelurahan Dinoyo yakni 94 unit dengan prosentase ketersediaan $43 \%$ terhadap keseluruhan populasi di RW 6. Angka prosentase ini berada pada level rendah, sedangkan jumlah tempat sampah tersedikit adalah RW 3 Kelurahan Dinoyo yakni 65 unit dengan prosentasi ketersediaan $25 \%$ terhadap keseluruhan populasi di RW 3.

2) Gerobak sampah : Jumlah gerobak sampah secara keseluruhan di lokasi penelitian adalah 12 unit, lokasi dengan gerobak sampah terbanyak adalah RW 3 Kelurahan Dinoyo dan RW 7 Kelurahan Tlogomas yakni masing-masing 3 unit dengan prosentase ketersediaan masing-masing $100 \%$ terhadap keseluruhan populasi di RW 3 \& RW 7, sedangkan jumlah gerobak sampah tersedikit masing-masing adalah RW 6 Kelurahan Dinoyo, RW 5 Kelurahan Tlogomas, dan RW 9 Kelurahan Jatimulyo yakni masing-masing 2 unit dengan prosentase ketersediaan masing-masing $100 \%$ terhadap keseluruhan populasi di RW 6, RW 5, dan RW 9.

3) TPS Sementara : Jumlah TPS sementara di lokasi penelitian hanya 1 unit yang terdapat di RW 3 Kelurahan Dinoyo.

b. Prasarana Limbah

Prasarana limbah meliputi jamban, septic tank, IPAL (Instalasi Pengolahan Air Limbah) komunal, dan MCK (Mandi Cuci Kakus) komunal. 
1) Jamban : Jumlah penggunaan jamban terbanyak adalah RW 7 Kelurahan Tlogomas yakni $524 \mathrm{kk}$ dengan prosentase ketersediaan $100 \%$ terhadap seluruh populasi di RW 7, sedangkan lokasi dengan pengguna jamban tersedikit adalah RW 6 Kelurahan Dinoyo yakni $218 \mathrm{kk}$ dengan prosentase ketersediaan $100 \%$.

2) Septic Tank: Penggunaan septic tank terbanyak adalah RW 9 Kelurahan Jatimulyo yakni $373 \mathrm{kk}$ dengan prosentase ketersediaan $88 \%$ terhadap keseluruhan populasi yang berada di RW 9, sedangkan lokasi dengan pengguna septic tank tersedikit adalah RW 6 Kelurahan Dinoyo yakni 118 kk dengan prosentase ketersediaan 54 \% terhadap keseluruhan populasi di RW 6.

3) IPAL Komunal : IPAL komunal terdapat di RW 3 dan RW 6 Kelurahan Dinoyo, serta RW 5 Kelurahan Tlogomas.

4) MCK Komunal : MCK Komunal hanya dimiliki oleh RW 7 Tlogomas sejumlah 1 unit dengan prosentase ketersediaan $100 \%$. Angka prosentase ketersediaan ini berada pada level tinggi.

c. Prasarana Drainase

Semua lokasi penelitian yang terdiri atas 5 RW (Rukun Warga) telah terlayani drainase. Adapun drainase di lokasi penelitian terdiri atas drainase primer dan sekunder dengan penampang terbuka dan tertutup.

\section{Tingkat Permasalahan Sanitasi}

Variabel yang digunakan adalah variabel fisik, pelaksanaan dan perilaku dari masing-masing elemen sanitasi yakni sampah, limbah, dan drainase. Adapun hasil analisa tingkat permasalahan sanitasi adalah sebagai berikut :

a. Tingkat Permasalahan Sampah

Berdasarkan analisa skoring yang telah dilakukan, didapatkan hasil skoring tingkat permasalahan sampah di lokasi penelitian sebagai berikut:

Tabel 4. Tingkat Permasalahan Sampah di Lokasi Penelitian

\begin{tabular}{clll}
\hline No & Lokasi & Hasil Skoring & Kelas \\
\hline 1 & RW 3 Kelurahan Dinoyo & 560 & I (tinggi) \\
2 & RW 6 Kelurahan Dinoyo & 470 & II (sedang) \\
3 & RW 5 Kelurahan Tlogomas & 440 & III (rendah) \\
4 & RW 7 Kelurahan Tlogomas & 490 & II (sedang) \\
5 & RW 9 Kelurahan Jatimulyo & 430 & III (rendah) \\
\hline
\end{tabular}

Sumber: Hasil Analisa , 2018

Berdasarkan tabel 4, diketahui bahwa persampahan RW 3 Kelurahan Dinoyo mendapatkan skor tertinggi yakni 560 dan berada pada kelas I (tinggi) yang berarti persampahan RW tersebut baik, sedangkan RW 9 Kelurahan Jatimulyo mendapatkan skor terendah yakni 430 dan berada pada kelas III (rendah) yang berarti persampahan RW tersebut buruk. RW 5 Kelurahan Tlogomas juga berada pada kelas III (rendah). Sementara itu RW 6 Kelurahan Dinoyo dan RW 7 Kelurahan Tlogomas masing-masing berada pada kelas II (sedang).

\section{b. Tingkat Permasalahan Limbah}

Berdasarkan analisa skoring yang telah dilakukan, didapatkan hasil skoring tingkat permasalahan limbah di lokasi penelitian sebagai berikut : 
Tabel 5. Tingkat Permasalahan Limbah di Lokasi Penelitian

\begin{tabular}{clll}
\hline No & Lokasi & Hasil Skoring & Kelas \\
\hline 1 & RW 3 Kelurahan Dinoyo & 540 & II (sedang) \\
2 & RW 6 Kelurahan Dinoyo & 540 & II (sedang) \\
3 & RW 5 Kelurahan Tlogomas & 510 & II (sedang) \\
4 & RW 7 Kelurahan Tlogomas & 640 & I (tinggi) \\
5 & RW 9 Kelurahan Jatimulyo & 420 & III (rendah) \\
& Jumlah & & \\
\hline
\end{tabular}

Sumber: Hasil Analisa, 2018

Berdasarkan tabel 5, diketahui bahwa limbah RW 7 Kelurahan Tlogomas mendapatkan skor tertinggi yakni 640 dan berada pada kelas I (tinggi) yang berarti limbah RW tersebut baik, sedangkan RW 9 Kelurahan Jatimulyo mendapatkan skor terendah yakni 420 dan berada pada kelas III (rendah) yang berarti limbah RW tersebut buruk. Sementara itu RW 3 dan RW 6 Kelurahan Dinoyo serta RW 5 Kelurahan Tlogomas masing-masing berada pada kelas II (sedang).

c. Tingkat Permasalahan Drainase

Berdasarkan analisa skoring yang telah dilakukan, didapatkan hasil skoring tingkat permasalahan drainase di lokasi penelitian sebagai berikut :

Tabel 6. Tingkat Permasalahan Drainase di Lokasi Penelitian

\begin{tabular}{rlll}
\hline No & Lokasi & Hasil Skoring & Kelas \\
\hline 1 & RW 3 Kelurahan Dinoyo & 250 & I (tinggi) \\
2 & RW 6 Kelurahan Dinoyo & 230 & III (rendah) \\
3 & RW 5 Kelurahan Tlogomas & 230 & III (rendah) \\
4 & RW 7 Kelurahan Tlogomas & 250 & I (tinggi) \\
5 & RW 9 Kelurahan Jatimulyo & 250 & I (tinggi) \\
& Jumlah & & \\
\hline
\end{tabular}

Sumber: Hasil Analisa , 2018

Tabel 7. Tingkat Permasalahan Sanitasi di Lokasi Penelitian

\begin{tabular}{clll}
\hline No & Lokasi & Hasil Skoring & Kelas \\
\hline 1 & RW 3 Kelurahan Dinoyo & 1.350 & I (tinggi) \\
2 & RW 6 Kelurahan Dinoyo & 1.240 & II (sedang) \\
3 & RW 5 Kelurahan Tlogomas & 1.180 & III (rendah) \\
4 & RW 7 Kelurahan Tlogomas & 1.380 & I (tinggi) \\
5 & RW 9 Kelurahan Jatimulyo & 1.100 & III (rendah) \\
& Jumlah & & \\
\hline
\end{tabular}

Sumber: Hasil Analisa, 2018

Berdasarkan tabel 6, diketahui bahwa drainase RW 3 Kelurahan Dinoyo, RW 7 Kelurahan Tlogomas, dan RW 9 Kelurahan Jatimulyo mendapatkan skor tertinggi yakni 250 dan berada pada kelas I (tinggi) yang berarti drainase RW tersebut baik, sedangkan RW 6 Kelurahan Dinoyo dan RW 5 Kelurahan Tlogomas masing-masing mendapatkan skor terendah yakni 230 dan berada pada kelas III (rendah) yang berarti drainase RW tersebut buruk. Dari perhitungan skoring tingkat permasalahan sampah, limbah, dan drainase 
didapatkan tingkat permasalahan sanitasi di lokasi penelitian dengan cara mengakumulasikan hasiil skoring elemen-elemen sanitasi tersebut. Berikut ini disajikan tabel tingkat permasalahan sanitasi di lokasi penelitian.

Berdasarkan tabel 7, diketahui bahwa sanitasi RW 7 Kelurahan Tlogomas mendapatkan skor tertinggi yakni 1.380 dan berada pada kelas I (tinggi) yang berarti sanitasi RW tersebut baik. Sanitasi RW 3 Kelurahan Dinoyo juga berada pada kelas I (tinggi), sedangkan RW 9 Kelurahan Jatimulyo mendapatkan skor terendah yakni 1.100 dan berada pada kelas III (rendah) yang berarti persampahan RW tersebut buruk. RW 5 Kelurahan Tlogomas juga berada pada kelas III (rendah). Sementara itu RW 6 Kelurahan Dinoyo berada pada kelas II (sedang).

\section{Konsep Penanganan Sanitasi}

Variabel yang digunakan adalah variabel fisik, pelaksanaan dan perilaku dari masingmasing elemen sanitasi yakni sampah, limbah, dan drainase. Konsep penanganan sanitasi ini didapatkan setelah menganalisa hasil wawancara dengan narasumber yang mengetahui cara penanganan masalah sanitasi di 5 lokasi tersebut. Adapun konsep penanganan sanitasi yang dimaksud adalah sebagai berikut :

a. Konsep Penanganan Sampah berikut ini :

Konsep penanganan masalah sanitasi untuk elemen sampah disajikan pada tabel

Tabel 8. Konsep Penanganan Sampah di Lokasi Penelitian

\begin{tabular}{|c|c|c|c|c|}
\hline No & Lokasi & $\begin{array}{l}\text { Permasalahan } \\
\text { Sampah }\end{array}$ & $\begin{array}{l}\text { Cara } \\
\text { Penanganan }\end{array}$ & $\begin{array}{l}\text { Konsep } \\
\text { Penanganan }\end{array}$ \\
\hline 1 & $\begin{array}{l}\text { RW } 3 \text { Kelurahan } \\
\text { Dinoyo }\end{array}$ & $\begin{array}{l}\text { Kurangnya sarana pembuangan } \\
\text { sampah terutama tong sampah. }\end{array}$ & $\begin{array}{l}\text { Pengadaan prasarana } \\
\text { pembuangan sampah } \\
\text { dengan melibatkan } \\
\text { peran masyarakat. }\end{array}$ & $\begin{array}{l}\text { Bantuan dan } \\
\text { partisipasi }\end{array}$ \\
\hline 2 & $\begin{array}{l}\text { RW } 6 \text { Kelurahan } \\
\text { Dinoyo }\end{array}$ & $\begin{array}{l}\text { Kurangnya sarana pembuangan } \\
\text { sampah terutama tong sampah. }\end{array}$ & $\begin{array}{l}\text { Pengadaan prasarana } \\
\text { pembuangan sampah } \\
\text { dengan melibatkan } \\
\text { peran masyarakat. }\end{array}$ & $\begin{array}{l}\text { Bantuan dan } \\
\text { partisipasi }\end{array}$ \\
\hline 3 & $\begin{array}{l}\text { RW } 5 \text { Kelurahan } \\
\text { Tlogomas }\end{array}$ & $\begin{array}{l}\text { Kurangnya sarana pembuangan } \\
\text { sampah terutama tong sampah. }\end{array}$ & $\begin{array}{l}\text { Pengadaan prasarana } \\
\text { pembuangan sampah } \\
\text { dengan melibatkan } \\
\text { peran masyarakat. }\end{array}$ & $\begin{array}{l}\text { Bantuan dan } \\
\text { partisipasi }\end{array}$ \\
\hline 4 & $\begin{array}{l}\text { RW } 7 \text { Kelurahan } \\
\text { Tlogomas }\end{array}$ & $\begin{array}{l}\text { Tidak adanya pemilahan skala } \\
\text { rumah tangga pada sampah } \\
\text { yang hendak dibuang, sehingga } \\
\text { sampah yang masih bisa didaur } \\
\text { ulang terbuang sia-sia dan } \\
\text { kurangnya sarana pembuangan } \\
\text { sampah terutama untuk tong } \\
\text { sampah. }\end{array}$ & $\begin{array}{l}\text { Pembuatan bank } \\
\text { sampah dengan sistem } \\
\text { perbankan dan } \\
\text { bantuan pengadaan } \\
\text { prasarana } \\
\text { pembuangan sampah } \\
\text { dari pemerintah. }\end{array}$ & $\begin{array}{l}\text { Percontohan } \\
\text { dan bantuan }\end{array}$ \\
\hline 5 & $\begin{array}{l}\text { RW } 9 \text { Kelurahan } \\
\text { Jatimulyo }\end{array}$ & $\begin{array}{l}\text { Kurangnya sarana pembuangan } \\
\text { sampah terutama tong sampah. }\end{array}$ & $\begin{array}{l}\text { Pengadaan prasarana } \\
\text { pembuangan sampah } \\
\text { dengan melibatkan } \\
\text { peran masyarakat. }\end{array}$ & $\begin{array}{l}\text { Bantuan dan } \\
\text { partisipasi }\end{array}$ \\
\hline
\end{tabular}

Sumber: Hasil Analisa, 2018

Berdasarkan tabel di atas, dapat lihat bahwa rata-rata penanganan persampahan di lokasi penelitian menggunakan konsep bantuan dan partisipasi, hanya RW 7 Kelurahan Tlogomas yang menggunakan konsep percontohan. 
b. Konsep Penanganan Limbah berikut ini :

Konsep penanganan masalah sanitasi untuk elemen limbah disajikan pada tabel

Tabel 9. Konsep Penanganan Limbah di Lokasi Penelitian

\begin{tabular}{|c|c|c|c|c|}
\hline No & Lokasi & $\begin{array}{l}\text { Permasalahan } \\
\text { Limbah }\end{array}$ & $\begin{array}{l}\text { Cara } \\
\text { Penanganan }\end{array}$ & $\begin{array}{l}\text { Konsep } \\
\text { Penanganan }\end{array}$ \\
\hline 1 & $\begin{array}{l}\text { RW } 3 \text { Kelurahan } \\
\text { Dinoyo }\end{array}$ & $\begin{array}{l}\text { Kurangnya sarana pembuangan } \\
\text { limbah yaitu septic tank. }\end{array}$ & $\begin{array}{l}\text { Pembuatan IPAL } \\
\text { komunal bantuan } \\
\text { dari pemerintah } \\
\text { dengan melibatkan } \\
\text { peran masyarakat. }\end{array}$ & $\begin{array}{l}\text { Bantuan dan } \\
\text { partisipasi }\end{array}$ \\
\hline 2 & $\begin{array}{l}\text { RW } 6 \text { Kelurahan } \\
\text { Dinoyo }\end{array}$ & $\begin{array}{l}\text { Kurangnya sarana pembuangan } \\
\text { limbah yaitu septic tank. }\end{array}$ & $\begin{array}{l}\text { Pembuatan IPAL } \\
\text { komunal bantuan } \\
\text { dari pemerintah } \\
\text { dengan melibatkan } \\
\text { peran masyarakat. }\end{array}$ & $\begin{array}{l}\text { Bantuan dan } \\
\text { partisipasi }\end{array}$ \\
\hline 3 & $\begin{array}{l}\text { RW } 5 \text { Kelurahan } \\
\text { Tlogomas }\end{array}$ & $\begin{array}{l}\text { Kurangnya sarana pembuangan } \\
\text { limbah yaitu septic tank. }\end{array}$ & $\begin{array}{l}\text { Pembuatan IPAL } \\
\text { komunal bantuan } \\
\text { dari pemerintah } \\
\text { dengan melibatkan } \\
\text { peran masyarakat. }\end{array}$ & $\begin{array}{l}\text { Bantuan dan } \\
\text { partisipasi }\end{array}$ \\
\hline 4 & $\begin{array}{l}\text { RW } 7 \text { Kelurahan } \\
\text { Tlogomas }\end{array}$ & $\begin{array}{l}\text { Kurangnya sarana pembuangan } \\
\text { air limbah terutama untuk jenis } \\
\text { limbah black water (tinja) } \\
\text { seperti jamban pribadi dan } \\
\text { septic tank sehingga masyarakat } \\
\text { BAB (Buang Air Besar) di } \\
\text { bantaran sungai Brantas. }\end{array}$ & $\begin{array}{lr}\text { Pembuatan } & \text { MCK } \\
\text { (Mandi, } & \text { Cuci, } \\
\text { Kakus) komunal } & \\
\text { Tangki AG (Agus } \\
\text { Gunarto) dengan } \\
\text { tahapan inisiasi } \\
\text { dan implementasi. }\end{array}$ & $\begin{array}{l}\text { Percontohan } \\
\text { dan } \\
\text { partisipasi }\end{array}$ \\
\hline 5 & $\begin{array}{l}\text { RW } 9 \text { Kelurahan } \\
\text { Jatimulyo }\end{array}$ & $\begin{array}{l}\text { Kurangnya } \\
\text { pembuangan limbah seperti } \\
\text { jamban pribadi dan septic tank. }\end{array}$ & Belum ditangani & $\begin{array}{l}\text { Belum } \\
\text { ditangani }\end{array}$ \\
\hline
\end{tabular}

Sumber: Hasil Analisa , 2018

Berdasarkan tabel 9, dapat lihat bahwa rata-rata penanganan limbah di lokasi penelitian menggunakan konsep bantuan dan partisipasi, hanya RW 7 Kelurahan Tlogomas yang menggunakan konsep percontohan.

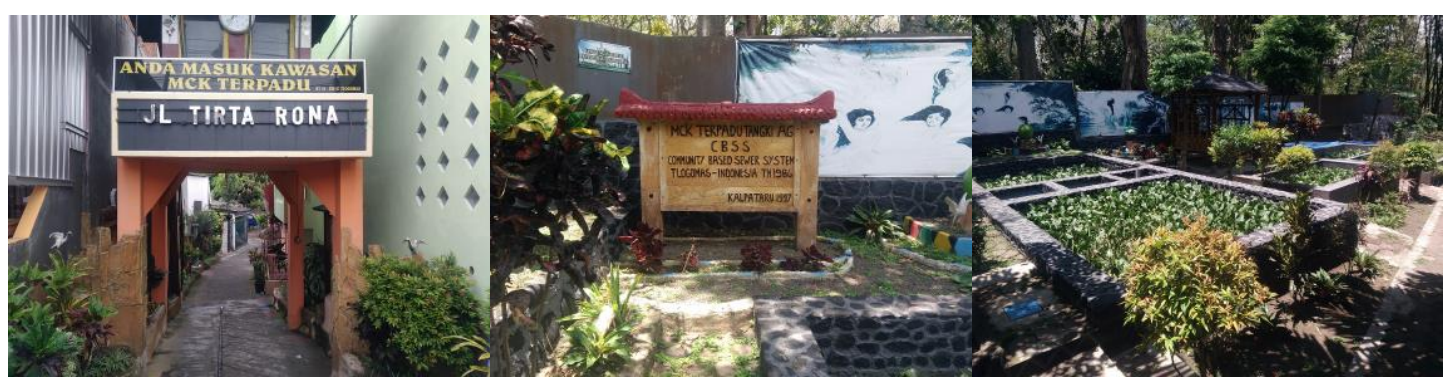

Sumber : Hasil observasi, 2018

Gambar 2. MCK Komunal Terpadu Tangki AG (Agus Gunarto) RW 7 Kelurahan Tlogomas 
c. Konsep Penanganan Drainase berikut ini :

Konsep penanganan masalah sanitasi untuk elemen limbah disajikan pada tabel

Tabel 10. Konsep Penanganan Drainase di Lokasi Penelitian

\begin{tabular}{|c|c|c|c|c|}
\hline No & Lokasi & $\begin{array}{l}\text { Permasalahan } \\
\text { Drainase }\end{array}$ & $\begin{array}{l}\text { Cara } \\
\text { Penanganan }\end{array}$ & $\begin{array}{l}\text { Konsep } \\
\text { Penanganan }\end{array}$ \\
\hline 1 & $\begin{array}{l}\text { RW } 3 \text { Kelurahan } \\
\text { Dinoyo }\end{array}$ & $\begin{array}{l}\text { Rusaknya kontruksi } \\
\text { drainase. }\end{array}$ & $\begin{array}{l}\text { Perbaikan konstruksi drainase dan } \\
\text { pengadaan gorong-gorong dari } \\
\text { pemerintah dengan melibatkan } \\
\text { peran masyarakat. }\end{array}$ & $\begin{array}{l}\text { Bantuan dan } \\
\text { partisipasi }\end{array}$ \\
\hline 2 & $\begin{array}{l}\text { RW } 6 \text { Kelurahan } \\
\text { Dinoyo }\end{array}$ & $\begin{array}{l}\text { Rusaknya kontruksi } \\
\text { drainase. }\end{array}$ & $\begin{array}{l}\text { Perbaikan konstruksi drainase dan } \\
\text { pengadaan gorong-gorong dari } \\
\text { pemerintah dengan melibatkan } \\
\text { peran masyarakat. }\end{array}$ & $\begin{array}{l}\text { Bantuan dan } \\
\text { partisipasi }\end{array}$ \\
\hline 3 & $\begin{array}{l}\text { RW } 5 \text { Kelurahan } \\
\text { Tlogomas }\end{array}$ & $\begin{array}{l}\text { Penyumbatan } \\
\text { sampah pada saluran } \\
\text { drainase. }\end{array}$ & $\begin{array}{l}\text { Pembersihan drainase oleh } \\
\text { masyarakat secara mandiri. }\end{array}$ & Partisipasi \\
\hline 4 & $\begin{array}{l}\text { RW } 7 \text { Kelurahan } \\
\text { Tlogomas }\end{array}$ & $\begin{array}{l}\text { Rusaknya kontruksi } \\
\text { drainase. }\end{array}$ & $\begin{array}{l}\text { Perbaikan konstruksi drainase dari } \\
\text { pemerintah dengan melibatkan } \\
\text { peran masyarakat. }\end{array}$ & $\begin{array}{l}\text { Bantuan dan } \\
\text { partisipasi }\end{array}$ \\
\hline 5 & $\begin{array}{l}\text { RW } 9 \text { Kelurahan } \\
\text { Jatimulyo }\end{array}$ & $\begin{array}{l}\text { Penyumbatan } \\
\text { sampah pada saluran } \\
\text { drainase. }\end{array}$ & $\begin{array}{l}\text { Pembersihan drainase oleh } \\
\text { masyarakat secara mandiri. }\end{array}$ & Partisipasi \\
\hline
\end{tabular}

Sumber: Hasil Analisa , 2018

Tabel 11. Konsep Penanganan Sanitasi di Lokasi Penelitian

\begin{tabular}{|c|c|c|c|c|c|}
\hline No & Lokasi & $\begin{array}{l}\text { Konsep } \\
\text { Penanganan } \\
\text { Sampah } \\
\end{array}$ & $\begin{array}{l}\text { Konsep } \\
\text { Penanganan } \\
\text { Limbah }\end{array}$ & $\begin{array}{l}\text { Konsep } \\
\text { Penanganan } \\
\text { Drainase } \\
\end{array}$ & $\begin{array}{l}\text { Kesimpulan Konsep } \\
\text { Penanganan }\end{array}$ \\
\hline 1 & $\begin{array}{l}\text { RW } 3 \text { Kelurahan } \\
\text { Dinoyo }\end{array}$ & $\begin{array}{l}\text { Bantuan dan } \\
\text { partisipasi }\end{array}$ & $\begin{array}{l}\text { Bantuan dan } \\
\text { partisipasi }\end{array}$ & $\begin{array}{l}\text { Bantuan dan } \\
\text { partisipasi }\end{array}$ & Bantuan dan partisipasi \\
\hline 2 & $\begin{array}{l}\text { RW } 6 \text { Kelurahan } \\
\text { Dinoyo }\end{array}$ & $\begin{array}{l}\text { Bantuan dan } \\
\text { partisipasi }\end{array}$ & $\begin{array}{l}\text { Bantuan dan } \\
\text { partisipasi }\end{array}$ & $\begin{array}{l}\text { Bantuan dan } \\
\text { partisipasi }\end{array}$ & Bantuan dan partisipasi \\
\hline 3 & $\begin{array}{l}\text { RW } 5 \text { Kelurahan } \\
\text { Tlogomas }\end{array}$ & $\begin{array}{l}\text { Bantuan dan } \\
\text { partisipasi }\end{array}$ & $\begin{array}{l}\text { Bantuan dan } \\
\text { partisipasi }\end{array}$ & Partisipasi & Partisipasi \\
\hline 4 & $\begin{array}{l}\text { RW } 7 \text { Kelurahan } \\
\text { Tlogomas }\end{array}$ & $\begin{array}{l}\text { Percontohan dan } \\
\text { bantuan }\end{array}$ & $\begin{array}{l}\text { Percontohan } \\
\text { dan partisipasi }\end{array}$ & $\begin{array}{l}\text { Bantuan dan } \\
\text { partisipasi }\end{array}$ & \multirow{2}{*}{$\begin{array}{l}\text { Pecontohan, bantuan dan } \\
\text { partisipasi } \\
\text { Partisipasi }\end{array}$} \\
\hline 5 & $\begin{array}{l}\text { RW } 9 \text { Kelurahan } \\
\text { Jatimulyo }\end{array}$ & $\begin{array}{l}\text { Bantuan dan } \\
\text { partisipasi }\end{array}$ & $\begin{array}{l}\text { Belum } \\
\text { ditangani }\end{array}$ & Partisipasi & \\
\hline
\end{tabular}

Sumber: Hasil Analisa , 2018

Berdasarkan tabel 10, dapat lihat bahwa rata-rata penanganan drainase di lokasi penelitian menggunakan konsep bantuan dan partisipasi. Berdasarkan uraian penanganan persampahan, limbah, dan drainase, dapat disimpulkan konsep penanganan sanitasi di lokasi penelitian adalah sebagai berikut : 
Berdasarkan tabel 11, dapat dilihat bahwa RW 3 dan RW 6 Kelurahan Dinoyo, serta RW 5 Kelurahan Tlogomas dan RW 9 Kelurahan Jatimulyo memiliki konsep penanganan sanitasi yang sama yaitu bantuan dan partisipatori, sedangkan RW 7 Kelurahan Tlogomas memiliki konsep yang berbeda yaitu percontohan, partisipatori, dan bantuan.

\section{KESIMPULAN}

Fokus dalam penelitian ini adalah penanganan sanitasi permukiman kumuh yang terdiri atas 3 elemen, yakni elemen limbah, persampahan, dan drainase pada 5 lokasi di Kecamatan Lowokwaru, Kota Malang yaitu Kelurahan Dinoyo tepatnya di RW 3 dan RW 6, Kelurahan Tlogomas tepatnya di RW 5 dan RW 7, dan Kelurahan Jatimulyo tepatnya di RW 9. Berdasarkan hasil analisa statistik deskriptif, ketersediaan prasarana sanitasi di lokasi penelitian masih kurang untuk prasarana persampahan yakni tempat sampah, sedangkan untuk prasarana limbah dan drainase sudah mencukupi. Berdasarkan hasil analisa skoring, hanya RW 3 Kelurahan Dinoyo dan RW 7 Kelurahan Tlogomas yang berada pada level tinggi (baik), sedangkan RW 5 Kelurahan Tlogomas dan RW 9 Kelurahan Jatimulyo berada pada level rendah (buruk), Untuk hasil analisa kluster, terdapat 3 macam konsep yang diterapkan di lokasi penelitian yaitu percontohan, partisipatori, dan bantuan.

\section{DAFTAR PUSTAKA}

Andini, Isti. 2014. Keputusan Siapa ? Partisipasi Komunal Pada Pelaksanaan Program Sanimas di Kelurahan Kadipiro, Kota Surakarta. Jurnal Perencanaan Wilayah dan Kota vol. 25, no. 2, hlm. 126-136.

Dalengkade, Lorensius Yanuar,dkk. 2011. Studi Pengolahan Air Limbah Untuk Kawasan Pemukiman Kabupaten Kubu Raya.

Enralin Jovanni. 2016. Akses Air Bersih dan Sanitasi Layak Pada Masyarakat Permukiman Kumuh di Kelurahan Jembatan Besi, Jakarta Barat. Tesis. Depok : Departemen Ilmu Kesejahteraan Sosial, Fakultas Ilmu Sosial dan Ilmu Politik, Universitas Indonesia.

Irman,Joy. 2011. Sistem Pengelolaan Limbah Setempat (On Site System). https://www.slideshare.net/metrosanita/sistem-pengolahan-air-limbah-setempat-onsite-system7869036. Tanggal akses : 1 Juli 2018.

Irman,Joy. 2011. Sistem Pengelolaan Limbah Terpusat (Off Site System). https://www.slideshare.net/metrosanita/sistem-pengolahan-air-limbah-terpusat-offsite-system. Tanggal akses : 1 Juli 2018.

J.O, Owoeye. 2013. Poverty, Sanitation And Public Health Nexus - Implications On Core Residential Neighbourhood Of Akure, Nigeria. International Journal of Developing Societies Vol. 2, No. 3, 2013, 96-104 DOI: $10.11634 / 216817831302448$.

Keputusan Walikota Malang Nomor 188.45/86/35.73.112/2015 Tentang Penetapan Lingkungan Perumahan dan Permukiman Kumuh.

Nurhapni, 2013. Kajian Pembangunan Sistem Drainase Berwawasan Lingkungan Di Kawasan Perumahan. Jurnal Perencanaan Wilayah dan Kota, Vol.11 No.1.

Peraturan Daerah (Perda) Nomor 12 Tahun 2014 tentang Rencana Pembangunan dan Pengembangan Perumahan dan Kawasan Permukiman (RP3KP) Kota Malang.

Peraturan Menteri Pekerjaan Umum Dan Perumahan Rakyat Republik Indonesia Nomor 02/Prt/M/2016 Tentang Peningkatan Kualitas Terhadap Perumahan Kumuh dan Permukiman Kumuh.

Riswan,dkk. 2011. Pengelolaan Sampah Rumah Tangga Di Kecamatan Daha Selatan. Jurnal Ilmu Lingkungan Vol.9, No. 1.

Rizal, Muhammad. 2011. Analisis Pengelolaan Persampahan Perkotaan (Studi Kasus Pada Kelurahan Boya Kecamatan Banawa Kabupaten Donggala). Jurnal SMARTek, Vol. 9 No. 2.

Wijaya, Donny Wahyu. 2016. Perencanaan Penanganan Kawasan Permukiman Kumuh Studi Penentuan Kawasan Prioritas Untuk Peningkatan Kualitas Infrastruktur Pada Kawasan Pemukiman Kumuh di Kota Malang. JIAP Vol. 2. No.1. 